\title{
Tantangan Implementasi 5G di Indonesia
}

\author{
Hamzah U. Mustakim \\ Institut Teknologi Telkom Surabaya \\ Surabaya, Indonesia \\ email:hamzah@ittelkom-sby.ac.id
}

\begin{abstract}
The development of $5 G$ network is expected to have a large impact on improving the economy and industry in Indonesia. Currently the government and operators are faced with several challenges to prepare for the implementation of the $5 G$ network which includes regulations and infrastructure that must be built. This study aims to provide some insights and considerations for the implementation of $5 G$ in Indonesia.
\end{abstract}

Keywords: 5G, IoT, uses cases, network.

Abstrak Pengembangan jaringan $5 G$ diharapkan memiliki dampak besar pada peningkatan ekonomi masyarakat dan industri di Indonesia. Saat ini pemerintah dan para operator dihadapkan pada beberapa tantangan untuk mempersiapkan implementasi jaringan $5 G$ yang meliputi regulasi dan insfrakstruktur yang harus dibangun. Penelitian ini bertujuan untuk memberikan beberapa pandangan dan pertimbangan untuk implementasi $5 G$ di Indonesia.

Kata kunci: 5G, IoT, skenario layanan, jaringan.

\section{PENDAHULUAN}

Evolusi teknologi komunikasi seluler membawa dampak besar pada kehidupan masyarakat dunia. Pada dekade terahir kita telah menyaksikan sebuah revolusi bagaimana cara manusia berkomunikasi, membagikan ide dan hidup melalui jaringan komunikasi nirkabel. Baik menggunakan jaringan seluler generasi ketiga (3G) dan generasi keempat (4G). Saat ini dunia sedang bersiap dengan generasi kelima (5G) sebagai sebuah platform yang dapat mengintegrasikan berbagai teknologi komunikasi nirkabel dengan berbagai jenis layanan didalamnya serta kemampuan untuk menyediakan koneksi kapanpun dan dimanapun kita berada. Berdasarkan Vigilante (2018) dan Dahmal (2016) eknologi 5G akan melampaui teknologi sebelumnya sehingga melahirkan sebuah istilah yang dinamakan networked society, yaitu sebuah koneksivitas yang dapat menjangkau semua hal disekitar kita.

Dengan kapasitas bandwidth yang lebih besar, data rate lebih tinggi dan tingkat delay yang kecil teknologi ini dapat memberikan peluang dan keuntungan kepada operator dengan menciptakan model bisnis baru (Ericsson, 2018). Menurut Badic (2016) hal ini dapat terjadi karena adanya peningkatan kualitas teknologi sehingga memungkinkan terbentuknya model layanan baru dan meningkatkan jumlah permintaan layanan pada operator oleh user. Sebagai contoh seperti dipaparkan oleh B. Raaf (2014), bahwa operator jaringan 4G melaporkan adanya peningkatan kapasitas trafik data sebesar $150 \%$ dibandingkan saat masih menggunakan jaringan 3G.

Berbeda dengan teknologi seluler sebelumnya, tujuan utama teknologi 5G adalah untuk memenuhi layanan komunikasi bergerak serta memberikan dukungan teknologi pada sektor ekonomi dan industri. Teknologi 5G akan menciptakan sebuah kondisi dimana konektivitas nirkabel berubah dari sesuatu hal yang memberikan nilai tambah menjadi sesuatu yang harus ada pada sektor industri. Kebutuhan pada teknologi nirkabel ini digunakan untuk mengumpulkan data dan membentuk sebuah analisis. Dari analisis data tersebut, Osseiran (2016) menyimpulkan bahwa data dan informasi adalah hal yang penting untuk pengembangan berbagai sektor industri.

Dibalik keunggulan dan peluang yang dapat dihasilkan dari teknologi $5 \mathrm{G}$ terdapat berbagai tantangan dalam implementasi dan pembangunan insfrakstruktur. Pada tulisan ini akan dibahas peluang dan berbagai tantangan yang sedang dihadapi untuk merealisasikan teknologi $5 \mathrm{G}$ di Indonesia. 


\section{SISTEM DAN ARSITEKTUR JARINGAN 5G}

Sistem jaringan 5G dibangun berdasarkan kebutuhan dan layanan di masa depan sebagaimana akan dijelaskan pada bagian 3. Secara kuantitatif parameter kinerja yang ditentukan oleh ITU-R (International Telecommunication Union) pada teknologi 5G melalui IMT-2020 (Gambar 1) adalah sebagai berikut:

- Peak data rate: berdasarkan kondisi ideal, data rate yang dapat dicapai adalah $20 \mathrm{Gbps}$ (downlink) dan 10Gbps (uplink).

- User experience data rate: merupakan data rate minimum yang diperoleh seorang user pada sebuah area. 100Mbps donwlink (DL) dan 50 Mbps untuk uplink (UL).

- Spectrum efficiency: didefinisikan sebagai rata-rata data troughput per spektrum yang dialokasikan pada sebuah cell. Untuk kondisi di dalam ruangan: 9 bps/Hz/cell (DL), 6.75 bps/Hz/cell (UL); Daerah urban: 7.8 bps/Hz/cell (DL), 5.4 bps/Hz/cell (UL); Daerah rural: 3.3 bps/Hz/cell (DL), 1.6 bps/Hz/cell (UL).

- Mobility: trafik data dapat berjalan normal pada user dengan kecepatan maksimal $500 \mathrm{~km} / \mathrm{jam}$.

- Latency: 4 ms untuk layanan Enhanced Mobile Broadband (eMBB), dan 1 ms untuk layanan Ultra Reliable and Low Latency Communications (URLLC).

- Connection density: jumlah total perangkat yang dapat terhubung pada jaringan adalah satu juta perangkat $/ \mathrm{km}^{2}$ untuk layanan Massive Machine Type Communications (mMTC).

- Network energy efficiency: mendukung sekema high sleep dan long sleep pada perangkat untuk menghemat konsumsi energi.

- Area traffic capacity: adalah total trafik yang dialokasikan pada sebuah besaran area yaitu sebesar $10 \mathrm{Mbps} / \mathrm{m}^{2}$ pada skema hotspot dalam ruangan.

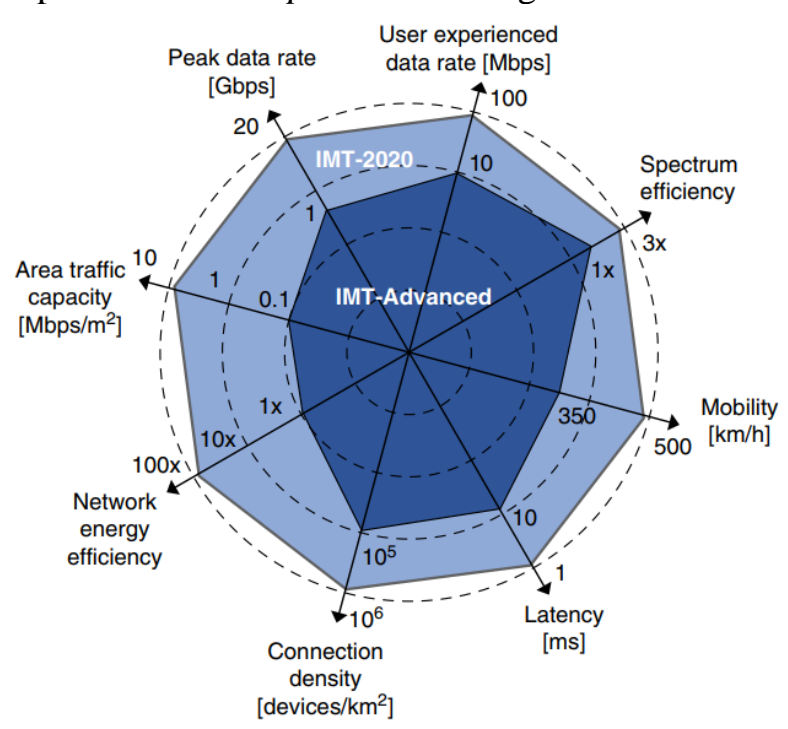

Gambar 1: Kemampuan utama 5G menurut IMT Vision dan Marsch (2018).

Evolusi sistem komunikasi 5G bertujuan untuk mendapatkan fleksibilitas arsitektur, kemampuan akses jaringan yang heterogen, dan integrasi lini bisnis secara vertikal dengan memanfaatkan teknologi SDN (Software Define Network) dan NFV (Network Functions Virtualizatiuon). Marsch (2018) menjelaskan bahwa untuk mendukung berbagai jenis penggunaan dan aplikasi, maka diperlukan beberapa perubahan pada jaringan konvensional yang telah ada dengan memecah elemen jaringan atau network function $(\mathrm{NF})$ menjadi modul dasar yaitu control plane $(\mathrm{CP})$ dan user plane (UP) sehingga memungkinkan terbentuknya logical architectures melalui interkoneksi dari CP dan UP seperti tertera pada Gambar 2. 


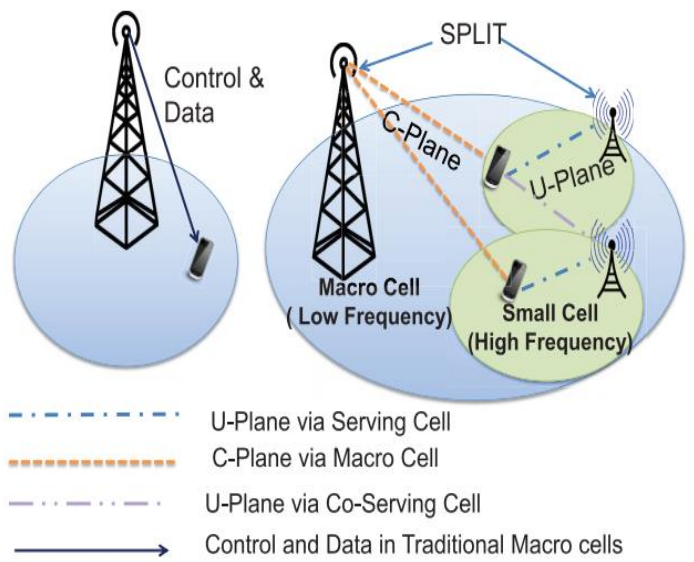

Gambar 2: Pemisahan CP dan UP pada Agiwal (2016).

Berdasarkan NGMN (2015) mekanisme untuk membuat jaringan yang telah ada ,seperti jaringan 4G, agar dapat digunakan untuk berbagai kebutuhan dan sekenario layanan adalah dengan cara melakukan pemotogan jaringan secara vertikal atau network slicing. Pada prinsipnya, pada 5G PPP (2015), network slicing adalah sebuah jaringan logika (Gambar 3) yang memiliki fungsi dan layanan tertentu untuk memenuhi kebutuhan yang spesifik sesuai dengan model bisnis yang diminta sehingga dapat menurunkan biaya operasional dan meningkatkan fleksibilitas jaringan seperti dijelaskan pada $\mathrm{E}$. N. ISG (2013) dan Zhang (2018).

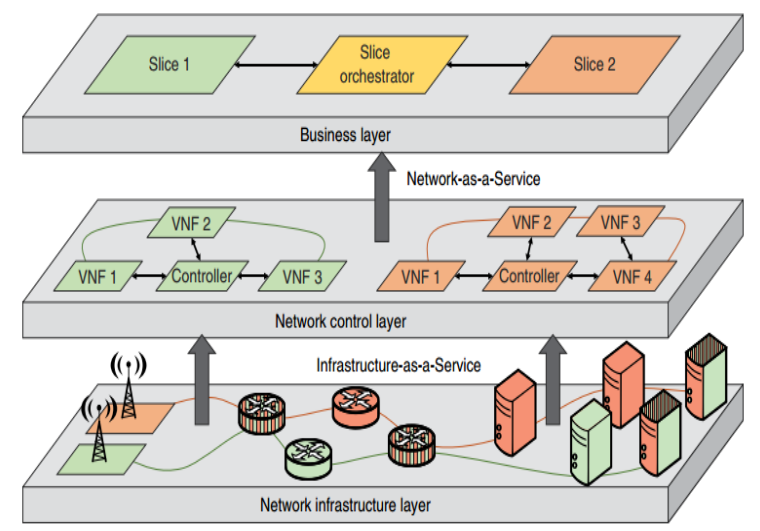

Gambar 3: Network slicing pada Marsch (2018).

IMT-2020 Promotion Group (2015) menjelaskan di dalam arsitektur jaringan 5G terdapat jaringan akses dengan kinerja tinggi dan jaringan inti (core network) yang berfungsi melakukan kontrol dan fowarding untuk memenuhi parameter kinerja yang telah ditentukan. Terdapat beberapa jenis teknologi jaringan akses yang dapat digunakan untuk menghubungkan base stasion (BS) dengan perangkat sehingga memungkinkan flesibilitas pada mekanisme akses jaringan dan mengoptimalkan pengunaan sumber daya jaringan. Habibi (2019). Fungsi kontrol dalam hal ini dilakukan oleh CP yang bertugas sebagai pembuat strategi kontrol secara global dalam sistem jaringan. Sedangkan utnuk fungsi fowarding dilakukan oleh foward plane (FP) yang bertugas meneruskan trafik data pada seluruh jaringan.

\section{SEKENARIO LAYANAN}

5G dikembangkan untuk dapat mendukung berbagai jenis penggunaan dan aplikasi yang berbeda. Tidak hanya memberikan layanan konvensional untuk komunikasi bergerak tapi juga untuk 
mendukung berbagai jenis industri sehingga secara tidak langsung berdampak pada pertumbuhan ekonomi dan kehidupan masyarakat.

Beberapa sektor industri dan ekonomi dimana teknologi komunikasi nirkabel dapat diterapkan menurut Osseiran (2016) adalah sebagai berikut:

- Pertanian: Penggunaan sensor dan aktuator untuk mengukur dan mengomuniksikan kondisi tanah, cuaca dan pertumbuhan tanaman.

- Automotif: Komunikasi nirkabel dikembangkan pada kendaraan automotif untuk mendukung sistem transportasi cerdas. Memungkinkan komunikasi antar kendaraan dan insfrakstruktur yang ada disekitarnya untuk menghindari kecelakaan dan kemacetan serta mendukung keselamatan berkendara.

- Konstruksi dan bangunan: Penggunaan sensor, aktuator yang terintegrasi dengan antena untuk sistem monitoring perangkat sehingga dapat menghemat energi. Selain itu juga Smart home system digunakan untuk keamanan rumah.

- Energi: Digunakan untuk monitoring, kontrol beban daya dan konsumsi energi.

- Keuangan: Termasuk didalamnya sistem perbankan dan belanja online yang membutuhkan koneksi internet secara luas. Dengan konsekuensi penguatan aspek keamanan pada proses transaksi keuangan saat menggunakan jaringan nirkabel.

- Kesehatan: Komunikasi nirkabel dapat dimanfaat pada dunia kesehatan sebagai sistem monitoring kesehatan pasien yang terhubung dengan rumah sakit sehingga dapat mempercepat penanganan medis ketika terjadi keluhan. Hal yang paling revolusioner adalah dokter dapat melakukan operasi bedah jarak jauh menggunakan robot.

- Manufaktur: Beberapa tugas teknis dan proses kontrol pada suatu pabrik dapat dilakukan dengan lebih efisien dan akurat menggunakan komunikasi nirkabel.

- Media: Saat ini media pemberitaan utama menggunakan video dengan resolusi tinggi. Teknologi 5G dapat memberikan pengalaman yang bagus untuk melihat video dengan format $4 \mathrm{~K}$ maupun 3D.

- Keamanan Publik: Kepolisisan, pemadam kebakaran, petugas penanggulangan bencana membutuhkan kehandalan jaringan komunikasi untuk dapat menangani berbagai masalah. Teknologi jaringan 5G sebagai salah satu bagian penting yang menjamin kehandalan komunikasi dengan implementasi SDN dan NFV. Sehingga dapat meniminalisir jaringan down pada saat keadaan darurat dan bencana seperti gempa bumi dan tsunami.

- Retail: Komunikasi nirkabel akan tetap berperan penting pada aspek ini. Terutama untuk mendukung layanan toko online, jasa transportasi dan pemesanan penginapan.

- Transportasi dan Logistik: Teknologi 5G membantu fungsi insfrakstruktur dan komunkasi pada jaringan kereta api, jalan raya dan proses pengiriman logistik baik melalui jalan darat dan jalur laut atau maritim.

- Industri lain: Sebagaimana industri pesawat terbang dan industri pertahanan yang selalu membutuhkan sistem komunikasi nirkabel untuk menjalankan fungsi produk mereka. Juga industri lain seperti kimia dan pertambangan.

Seluruh penggunaan dan aplikasi pada teknologi $5 \mathrm{G}$ dapat dikelompokkan menjadi tiga sekenario utama (Gambar 4):

- Enhanced Mobile Broadband (eMBB): Adalah sekenario penggunaan untuk layanan komunikasi data dan multimedia.

- Ultra Reliable and Low Latency Communications (URLLC): Berhubungan dengan aplikasi yang membutuhkan kinerja jaringan sangat baik dan sangat sensitif terhadap delay dan latency. Sebagai contoh pada sistem keamanan transportasi, operasi bedah jarak jauh, dan sistem kontrol industri manufaktur. Teknologi ini dibutuhkan sebagai pondasi dari industri 4.0.

- Massive Machine Type Communications (mMTC): Digunakan pada aplikasi yang menggunakan banyak perangkat. Setiap perangkat terhubung dengan internet serta 
mengirimkan data dalam kapasitas kecil yang tidak sensitif terhadap delay seperti alat monitor cuaca dan alat motitoring pertanian yang menggunakan sensor untuk memantau kondisi tanah.

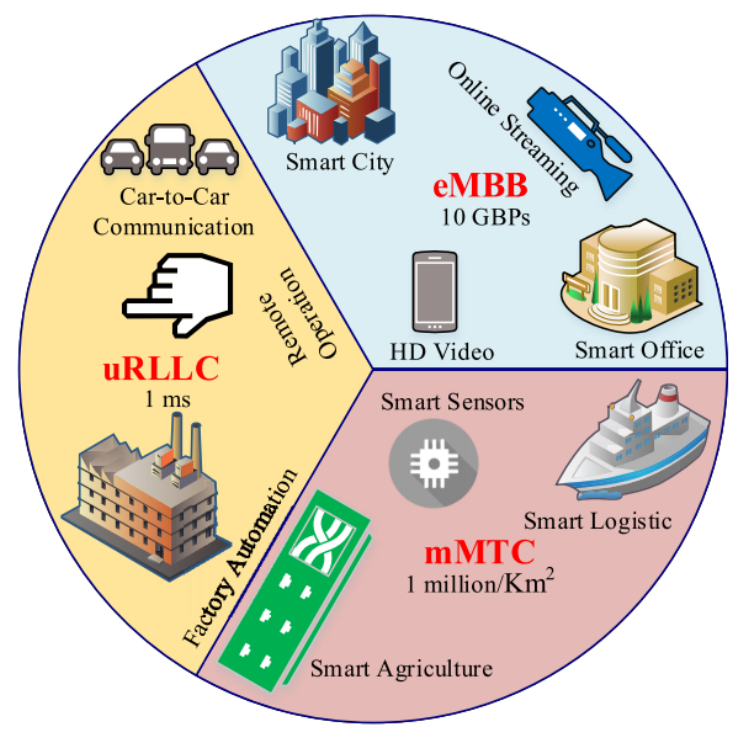

Gambar 4: Skenario layanan 5G pada Habibi (2019).

Masing-masing sekenario memiliki indikator kinerja dan quality of service (QoS) yang harus dipenuhi agar dapat memberikan kualitas layanan yang baik seperti dijelaskan oleh Andriyanto (2017) berdasarkan IMT Vision tertera pada Gambar 5:

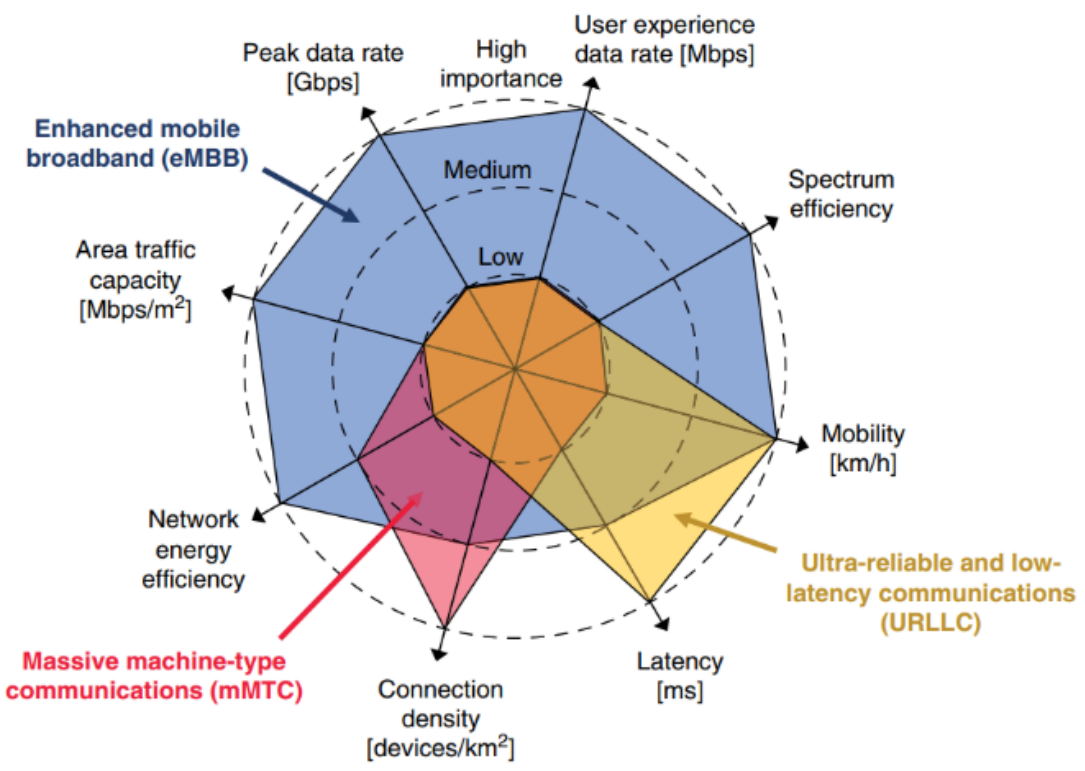

\section{TANTANGAN IMPLEMENTASI}

Saat ini beberapa negara melalui operator telekomunikasi telah menggelar jaringan 5G dan melakukan pengujian terhadap kinerjanya sebelum diluncurkan secara resmi pada tahun 2020 . Sedangkan di Indonesia menurut Kominfo (2019) akan diluncurkan tahun 2022. Jika kita melihat perkembangan generasi teknologi sebelumnya, maka dapat dipastikan bahwa setiap generasi teknologi baru akan membuka peluang baru baik dari sisi operator dan pelanggan atau masyarakat. Operator akan diuntungkan karena terbentuknya jenis layanan baru, sebagaimana yang telah dibahas sebelumnya, sehingga memberikan peluang terhadap peningkatan pendapatan. Dan dari sisi 
masyarakat sebagai user dapat meningkatkan perekonomian melalui penggunaan teknologi internet. Pada saat yang sama para operator juga mewaspadai besarnya peningkatan biaya investasi yang harus dikeluarkan untuk membangun insfrakstruktur jaringan $5 \mathrm{G}$ serta pengembangan jaringan $4 \mathrm{G}$ untuk memenuhi permintaan user. Menurut analisis Grijpink (2018), akan terjadi peningkatan capex (capital expenditure) sebesar $60 \%$ pada tahun 2020-2025.

Untuk memenuhi parameter kinerja yang telah ditentukan pada teknologi 5G maka pembangunan dan pengembangan insfrakstruktur adalah hal yang harus dilakukan para operator di Indonesia. Dalam hal ini operator harus berinvestasi pada semua domain jaringan yaitu: spektrum frekuensi, jaringan akses atau radio accsess network (RAN), dan transmisi yang berhubungan dengan core network. Berikut ini adalah tantangan implementasi dari masing-masing domain jaringan tersebut:

- Spektrum frekuensi: merupakan sumber daya utama dari semua RAN. Kapasitas trafik data pada teknologi $5 \mathrm{G}$ akan meningkat secara signifikan dan disertai dengan kebutuhan pada cakupan (coverages), kehandalan (reliability) serta troughput jaringan akses. Menurut Osseiran (2014) untuk meningkatkan kapasitas dan kinerja jaringan tersebut diperlukan penambahan akuisisi spektrum frekuensi yang sesuai dengan skema layanan yang digunakan pada 5G dengan indikator kapasitas trafik data seribu kali lebih besar dan data rate hingga seratus kali dari teknologi yang ada saat ini sehingga jaringan 5G akan mengakomodasi trafik data dengan orde mulai dari kbps hingga Gbps. Jika dilihat dari skema layanan pada 5G maka terdapat tiga jajaran spektrum frekuensi yang dapat digunakan yaitu dibawah $1 \mathrm{Ghz}$, diantara $1 \mathrm{Ghz}$ dan $6 \mathrm{Ghz}$ dan di atas $6 \mathrm{Ghz}$. Konsekuensi dari perbedaan spektrum frekuensi tersebut adalah sistem $5 \mathrm{G}$ harus mampu beroperasi pada beberapa bandwidth yang berbeda dengan sekenario pengembangan sistem komunikasi yang berbeda juga mulai dari spektrum dibawah $1 \mathrm{GHz}$ hingga $100 \mathrm{GHz}$. Semakin tinggi spektrum frekuensi maka dapat meningkatkan data rate dengan konsekuensi luas cakupan yang semakin kecil (Gambar 6). Bedasarkan ITU Radio Regulation (2016), spektrum frekuensi yang saat ini digunakan untuk layanan komunikasi bergerak adalah $1886 \mathrm{Mhz}$. Saat ini di Indonesia pada range frekuensi $1800 \mathrm{MHz}$, menurut Direktorat Penataan Sumber Daya (2018), telah dialokasikan untuk layanan komunikasi bergerak oleh beberapa operator: Hutchison 3 Indonesia, Indosat, Telkomsel dan XL Axiata (Tabel 1). Peluang penggunaan spektrum frekuensi dibawah $1 \mathrm{Ghz}$ IoT ada pada $700 \mathrm{MHz}$ yang saat ini digunakan untuk siaran TV analog. Dalam tulisannya Ekawibowo (2018) jika migrasi TV anaog menuju TV digital berhasil dilakukan maka akan ada alokasi bandwidth sebesar $112 \mathrm{MHz}$ yang dapat digunakan untuk 5G. Spektrum ftekuensi $700 \mathrm{MHz}$ dapat digunakan untuk skenario layanan Internet of Things (IoT) yang membutuhkan cakupan area luas.

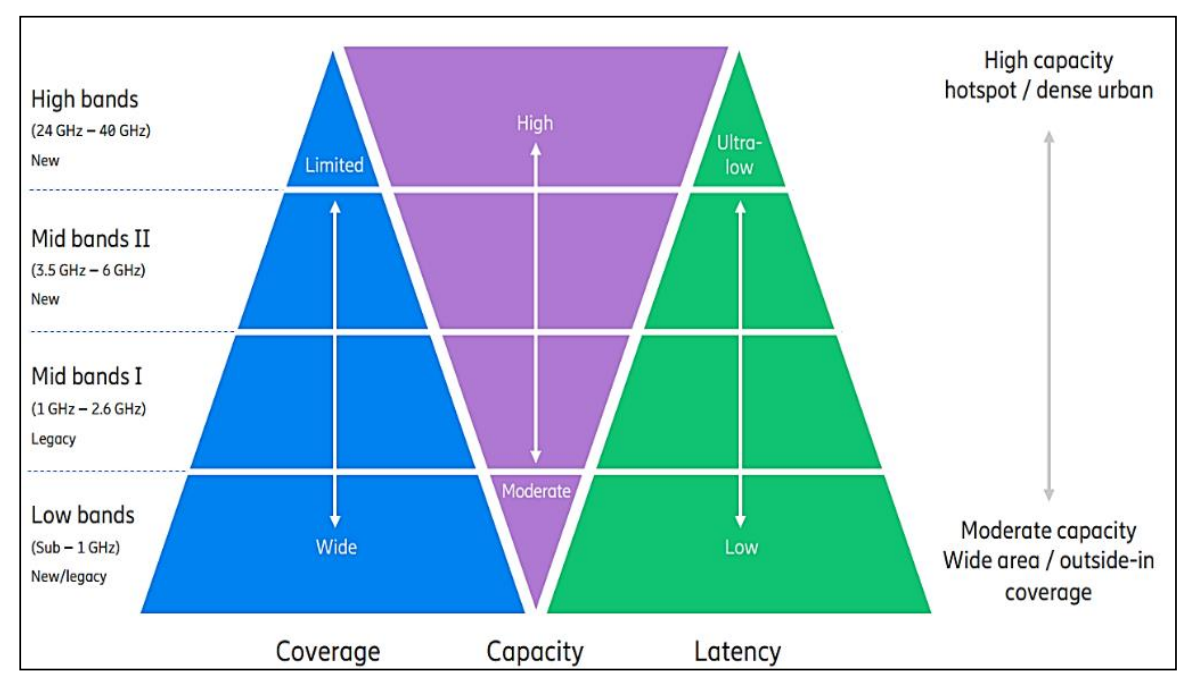


Gambar 6: Spektrum Frekuensi 5G oleh Ericsson (2018).

Untuk spektrum frekuensi antara $1 \mathrm{Ghz}$ dan $6 \mathrm{Ghz}$ atau mediun frequency bands terdapat kandidat, selain frekuensi $2.3-2.4 \mathrm{GHz}$ yang telah digunakan untuk 4G LTE yaitu 3.3-4.2GHz sebagaimana tertera pada Peraturan Menteri Kominfo Nomor 25 Tahun 2014. Berdasarkan The World Radiocommunication Conference (WRC) tidak menentukan frekuensi tertentu yang akan digunakan, namun terdapat kesamaan untuk peluncuran 5G di Eropa dan Asia bahwa akan menggunakan spektrum frekuensi $3.5 \mathrm{GHz}$. Frekuensi ini ideal untuk dikembangkan untuk layanan pada daerah perkotaan dengan kebutuhan kinerja trafik data yang tinggi. Namun saat ini berdasarkan regulasi yang masih berlaku saat ini pada ITU regional 3 termasuk Indonesia frekuensi $3.5 \mathrm{GHz}$ juga masih digunakan untuk komunikasi satelit dari angkasa ke bumi (Tabel 2). Artinya dibutuhkan regulasi baru untuk penataan spektrum frekuensi yang akan digunakan untuk 5G.

Selanjutnya penggunaan spektrum frekuensi di atas $6 \mathrm{Ghz}$ adalah gelombang milimetrik atau mmWave dengan rentang frekuensi antara $30 \mathrm{GHz}$ sampai $300 \mathrm{GHz}$ yang diharapkan dapat mendukung kinerja jaringan akses untuk mencapai data rate pada orde Gigabit/detik (Gbps). Tantangan utama pada gelombang milimetrik adalah sangat rentan terhadap path loss, lintasan non-line-of-sight serta noise karena menggunakan frekuensi carrier yang tinggi dan bandwidth yang lebar sebagaimana dijelaskan juga oleh Al-Ogaili (2016). Faktor cuaca juga menjadi salah satu pertimbangan dalam mendesain model propagasi untuk gelombang milimetrik 30GHz pada daerah tropis seperti Indonesia. Berdasarkan Nandi (2017) redaman yang dihasilkan pada saat hujan dapat mencapai $8 \mathrm{~dB}$.

Tabel 1: Alokasi spektrum untuk komunikasi bergerak di Indonesia oleh Direktorat Penataan Sumber Daya.

\begin{tabular}{|l|l|l|l|l|l|l|l|}
\hline \multirow{2}{*}{$\begin{array}{l}\text { Perusahaa } \\
\mathrm{n}\end{array}$} & \multicolumn{7}{|c|}{ Frekuensi dan Bandwidth (MHz) } \\
\cline { 2 - 9 } & 450 & $\begin{array}{l}80 \\
0\end{array}$ & $\begin{array}{l}90 \\
0\end{array}$ & $\begin{array}{l}180 \\
0\end{array}$ & $\begin{array}{l}210 \\
0\end{array}$ & $\begin{array}{l}230 \\
0\end{array}$ & Total \\
\hline H3I & - & - & - & 20 & 30 & - & 50 \\
\hline Indosat & - & - & 25 & 40 & 30 & - & 95 \\
\hline STI & 15 & - & - & - & - & - & 15 \\
\hline Smartfren & - & 22 & - & - & - & - & 22 \\
\hline Smarttel & - & - & - & - & - & 30 & 30 \\
\hline Telkomsel & - & - & 30 & 45 & 30 & 30 & 135 \\
\hline XL Axiata & - & - & 15 & 45 & 30 & - & 90 \\
\hline \multicolumn{7}{|l}{ Total Bandwidth } \\
\hline
\end{tabular}

Tabel 2: Alokasi spektrum frekuensi 3400-4200MHZ pada Permen Kominfo No. 25 Tahun 2014.

\begin{tabular}{|c|c|c|}
\hline Frekuensi (MHz) & Region 3-ITU & Indonesia \\
\hline & & Satelit tetap \\
& Satelit tetap & (Angkasa ke Bumi) \\
$3400-3500$ & (Angkasa ke Bumi) & Radiolokasi: 5.433 \\
& Radiolokasi: 5.433 & 5.282 5.432 5.432A \\
& 5.2825 .432 5.432A & INS28 \\
\hline
\end{tabular}




\begin{tabular}{|c|c|c|}
\hline \multirow{3}{*}{$3500-3600$} & $\begin{array}{c}\text { Satelit tetap } \\
\text { (Angkasa ke Bumi) } \\
\text { Radiolokasi: 5.433 }\end{array}$ & $\begin{array}{c}\text { Satelit tetap } \\
\text { (Angkasa ke Bumi) } \\
\text { Radiolokasi: 5.433 } \\
\text { INS28 }\end{array}$ \\
\hline \multirow{3}{*}{$3600-3700$} & $\begin{array}{c}\text { Satelit tetap } \\
\text { (Angkasa ke Bumi) } \\
\text { Radiolokasi: 5.435 }\end{array}$ & $\begin{array}{c}\text { Satelit tetap } \\
\text { (Angkasa ke Bumi) } \\
\text { Radiolokasi: } 5.435 \\
\text { INS28 }\end{array}$ \\
\hline $3700-4200$ & $\begin{array}{c}\text { Satelit tetap } \\
\text { (Angkasa ke Bumi) }\end{array}$ & $\begin{array}{c}\text { Satelit tetap } \\
\text { (Angkasa ke Bumi) } \\
\text { Radiolokasi: INS28 }\end{array}$ \\
\hline
\end{tabular}

- Insfrakstuktur RAN: pengembangan insfrakstuktur jaringan akses radio dan radio access technology (RAT) untuk jaringan 5G mengacu pada 3GPP Realese 15 menggunakan dua skema yaitu standalone New Radio dan non-standalone New Radio. sebuah perangkat (user equipment / UE) dapat mengakses jaringan 5G melalui jaringan 4G LTE yang sudah tersedia ataupun langsung melalui New Radio Technology (NR) untuk dapat terhubung dengan Evolved Packet Core (EPC) maupun 5G Core (5GC) sebagai jaringan inti 5G Sehingga setiap operator yang ingin menggelar jaringan 5G harus dapat mendukung UE, jaringan radio, core network, dan manajemen produk dengan baik. Termasuk pengembangan pico cells, femto cells, dan micro cells yang dikombinasikan dengan macro cells yang sudah ada sekarang. Skema non-standalone dengan jaringan 4G LTE yang sudah ada adalah alternatif terbaik yang dapat digunakan untuk menggelar jaringan 5G dengan beberapa keuntungan menurut Cagenius (2018) yaitu pada aspek kinerja karena memungkinkan kombinasi penggunaan spektrum NR untuk downlink dan lower-band LTE sebagai channel uplink.

- Transmisi: Evolusi dari RAN juga berpengaruh pada perubahan transport network untuk memperoleh kinerja jaringan yang tinggi. Hal ini dapat tercapai dengan dukungan teknologi transmisi yang bagus. Untuk mencapai data rate maksimum sebesar 20Gbps (DL) dan $10 \mathrm{Gbps}$ (UL). Maka operator harus menambah instalasi kabel fiber optik dalam skala besar terutama untuk pengembangan small-cells pada daerah perkotaan. Pada Dat (2019) dan Zeb (2019) instalasi fiber optik ini dilakukan pada sisi fronthoul untuk mengirimkan sinyal dari base band processing unit (BBU) menuju antena. Dan pada sisi backhoul untuk menghubungkan BBU menuju core network (Gambar 7).

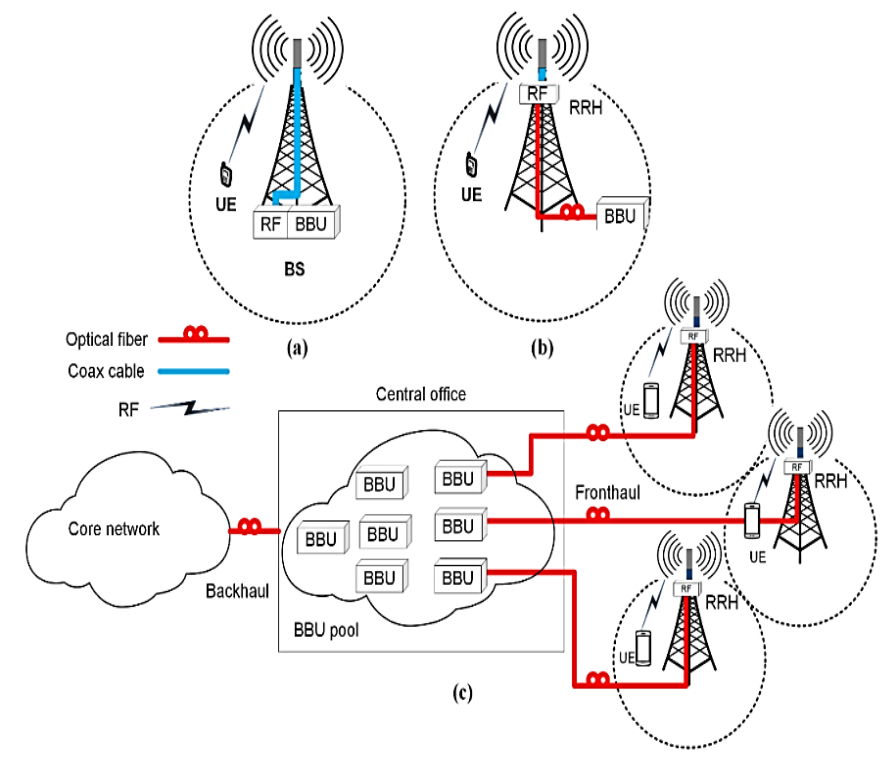


Gambar 7: Perbedaan arsitektur base station konvesional (a) dan (b) dengan arsitektur baru menggunakan fiber optik oleh Zeb (2019).

\section{KESIMPULAN}

Untuk melakukan implementasi jaringan 5G diperlukan persiapan yang meliputi spektrum frekuensi dan regulasi oleh pemerintah. Selain itu kebutuhan insfrakstruktur jaringan yang meliputi RAN dan saluran transmisi menggunakan kabel fiber optik harus dilakukan oleh para operator.

\section{DAFTAR PUSTAKA:}

3GPP Release 15 specifications. (2016) e.g. TS 23.501, TS 38.401, from: www.3gpp.org/release-15. 5G PPP. (2016). 5G empowering verticals.

A. Osseiran, et al, Scenarios for $5 \mathrm{G}$ mobile and wireless communications: The vision of the METIS project, IEEE Com Mag, vol. 52, no. 5.

Afif Osseiran. (2016). 5G Mobile and Wireless Communications Technology: Cambridge University Press.

B. Raaf et al. (2014). Key technology advancements driving mobile communications from generation to generation. Intel Technology Journal, Volume 18, Issue 1.

Biljana Badic et al. (2016). Rolling Out 5G: Use Cases, Applications, and Technology Solutions: Intel Corp.

Direktorat Penataan Sumber Daya. (2018). Overview Pita Frekuensi Seluler Indonesia,.

E. N. ISG. (2013). Network Functions Virtualisation (NFV) Architectural Framework: ETSI GS NFV $002 \mathrm{~V} 1.1 .1$.

Ericsson. (2018). 5G deployment considerations.

Erik Dahlmal et al. (2016). 4G ,LTE-Advance Pro and The Road to 5G: Elsevier Ltd.

F. Al-Ogaili and R. M. Shubair. (2016). Millimeter-wave mobile communications for 5G: Challenges and opportunities, 2016 IEEE International Symposium on Antennas and Propagation (APSURSI). Fajardo.

F. Andriyanto and M. Suryanegara. (2017) The QoE assessment model for 5G mobile technology. 2017 International Conference on Broadband Communication, Wireless Sensors and Powering (BCWSP). Jakarta.

Ferry Grijpink et al. (2018). The road to 5G: The inevitable growth of infrastructure cost: McKinsey Telecommunications.

I. Parvez et al. (2018). A Survey on Low Latency Towards 5G: RAN. Core Network and Caching Solutions, in IEEE Communications Surveys \& Tutorials. vol. 20, no. 4, pp. 3098-3130.

IMT Vision. (2015). Framework and overall objectives of the future development of IMT for 2020 and beyond.

IMT-2020 (5G) Promotion Group. (2015). 5G Network Technology Architecture.

ITU Radio Regulations. (2016). ITU.

K. Zeb. (2018). High Capacity Mode Division Multiplexing Based MIMO Enabled All-Optical Analog Millimeter-Wave Over Fiber Fronthaul Architecture for 5G and Beyond. IEEE Access, vol. 7, pp. 89522-89533.

Kementerian Komunikasi dan Informatika RI. (2014). Peraturan Menteri Nomor 25 Tahun 2014 Tentang Tabel Alokasi Frekuensi Radio Indonesia.

Kominfo. (2019). Pemerintah Buka Wacana Lelang Frekuensi 5G Pada 2022, Website Resmi Kementerian Komunikasi dan Informatika RI. from 
https://www.kominfo.go.id/content/detail/15420/pemerintah-buka-wacana-lelang-frekuensi5g-pada-2022/0/sorotan_media.

M. A. Habibi et al. (2019). A Comprehensive Survey of RAN Architectures Toward 5G Mobile Communication System. IEEE Access, vol. 7, pp. 70371-70421.

M. Agiwal. (2016). Next Generation 5G Wireless Networks: A Comprehensive Survey. IEEE Communications Surveys \& Tutorials: vol. 18, no. 3, pp. 1617-1655.

Marco Vigilante et al. (2018). 5G and E-Band Commu nication Circuit s in Deep-Scale d CMOS: Springer International Publishing AG.

NGMN. (2015). 5G White Paper.

P. T. Dat. (2018). Seamless Convergence of Fiber and Wireless Systems for 5G and Beyond Networks. Journal of Lightwave Technology, vol. 37, no. 2, pp. 592-605.

Patrick Marsch et al. (2018). 5G System Design: Wiley.

S. A. Ekawibowo et al. (2018). Analysis of 5G Band Candidates for Initial Deployment in Indonesia. 2018 4th International Conference on Wireless and Telematics (ICWT). Nusa Dua.

S. Nandi and D. Nandi. (2017). Comparative study of rain attenuation effects for the design of $5 \mathrm{G}$ millimeter wave communication between tropical and temperate region. 2017 Devices for Integrated Circuit (DevIC). Kalyani.

T. Cagenius. (2018). Simplifying the 5G ecosystem: Ericsson Technology Review.

Ying Zhang. (2018). Network Function Virtualization: Concepts and Applicability in 5G Networks: John Wiley \& Sons, Inc. 